\title{
ONLINE STRATEGY OF PRINTED MEDIA COMPANY (Case Study of www.nirmalamagazine.com)
}

\author{
Veronica Sri Utami ${ }^{1}$ \\ Fakultas Ilmu Komunikasi Universitas Budi Luhur
}

\begin{abstract}
ABSTRAK
Aktivitas online terpopuler yang ke-6 menurut Yahoo TNS Net Index 2010 adalah membaca berita online. Perilaku ini tentu akan mempengaruhi bisnis media konvensional, termasuk media cetak. Tujuan dari penelitian ini adalah untuk mendeskripsikan strategi online yang digunkana oleh majalah Nirmala, salah satu majalah kesehatan yang memiliki tingkat pembaca cukup tinggi di tahun 2005 , namun menurun di tahun-tahun berikutnya. Majalah Nirmala mengembangkan websitenya www.nirmalamagazine.com - di tahun 2009. Mereka juga membuat akun-akun di media social, dan mengirimkan email blast sebagai sarana penyebar informasi. Peneliti menggunakan metode kualitatif untuk penelitian ini, dengan teknik studi kasus. Untuk mengumpulkan data, digunakan wawancara, review dokumen, dan observasi lapangan. Hasilnya menunjukkan bahwa website majalah Nirmala, yang didukung juga dengan akun di social media dan program email marketing, sebenarnya bisa menjadi alat yang berguna untuk mendukung bisnis media cetak mereka. Beberapa fungsi dari bentuk media online majalah Nirmala ini antara lain: fungsi komunikasi marketing, media untuk beriklan secara online, membangun merk secara online, layanan pelanggan, dan menjalin relasi dengan pembaca. Sayangnya, website ini kurang dikelola secara optimal: pemahaman tentang keuntungan dari media online, target pasar, budget, infrastruktur, tim pengelola, serta sinergi antardivisi adalah hal-hal yang perlu dibenahi.
\end{abstract}

\section{Kata kunci: Internet, media cetak, strategi online, majalah kesehatan}

\section{ABSTRACT}

The sixth most popular online activities according to Yahoo TNS Net Index 2010 is reading news online. This behavior change will significantly affect conventional media business, including print media. The purpose of this research is to describe online strategy applied by Nirmala magazine. This magazine is one of the health magazines that secured significant readership on 2005, but somehow decreased its popularity in the following years. Nirmala magazine developed their own website at 2009, with the URL www.nirmalamagazine.com. It also established social media accounts and sent email blasts The print media company will certainly benefit from a strategy when they go online, which allows them to obtain the optimum benefit for the business. For this research, the author used qualitative methodology, predominantly case study technique. Interview, document review, and field observation are the methods used to collect data. The results and data analysis led to the findings that Nirmala website, supported by social media account and email marketing program, are actually useful as the tools to support their existing business. There are several functions served by this online form, among others, marketing communication function, medium to attract online advertisement, online brand building, customer service, and relationship building. Unfortunately, this website is not managed properly. Lack of understanding about optimum benefit from online side, poor decision about target market, budget, infrastructure, strategy and online management team, and also lack of synergy with all business units are some weaknesses that require improvement.

Keywords: Internet, print media, online strategy, health magazine

${ }^{1}$ Veronica Sri Utami; Email veronicasriutami@gmail.com 


\section{INTRODUCTION}

It is hardly surprising, that with accessibility of any information for the Internet at any given time, without having to purchase the daily newspapers, weekly or biweekly magazines, the number of printed media reader has decreased significantly.

The most ironic story about negative effect of the Internet on printed media happened to the Christian Science Monitor Daily, daily newspaper in United States that had been published since 1908, and already won seven Pulitzer awards. Christian Science Monitor Daily had to stop their daily printed version at 2008, because the decrease of their sales, from 223,000 copies in the 1970's to merely 50,000 copies in 2008 .

The same condition happened in Indonesia. Media Index Survey conducted by AC Nielsen Media shows that generally print media readership declined since 2005. A survey using stratified random sampling method, with face-to-face interviews to 14,000 respondents in nine major cities in Indonesia at the third quarter of 2009 indicated that newspaper reader numbers declined significantly from $28 \%$ in the first quarter of 2005 , to only $19 \%$ in the second quarter of 2009.

The same condition occurred in other forms of print media: magazines and tabloids. In the second quarter of 2009, tabloids only reached $13 \%$ and magazine $12 \%$ from total population, compared to $20 \%$ acquisition from total population in the first quarter of 2005 (Kompas.com).

Meanwhile, customer acquisition of internet media increased significantly as the number of internet users spread widely. In the second quarter of 2005, the consumers of the Internet media reached $17 \%$, a significant surge from $8 \%$ at 2005 . Therefore, it can be understood that more and more news portals are being developed by business people to serve people's need and to increase the income from this business.

The development of online media in Indonesia started in 1998 when detik.com was established. This site provided breaking news to its readers. Detik.com became the champion for this business with approximately six to seven million visitors every day and 76 billion rupiahs income per year, up to the end of 2007. (Koran Tempo, February 2008). In 2010 - before $100 \%$ acquisition of Para Group - the income of Detik.com was recorded at 120 billion with the net profit of 20 billion. (tempointeraktif.com)

According to Alexa.com, it is estimated that detik.com has 164.250 visitors every day, with estimated daily ads revenue recorded at $\$ 3.716,9$ (http://www.sitelogic.biz (accessed on August 14th, 2011).

The significant number shows that this is a serious business. It is only 
to be expected that detik.com then had a lot of competitors at that time, such as astaga.com, satunet, Mweb, Lippostar, Kopitime, and BolehNet, although some of these portals discontinued their business for some particular reasons.

\section{A Challenge For Print Media}

The increasing number of online media as an impact of the Internet development, accompanied with the trend of declining level of print media consumption, should become a concern for print media business. It is a challenge for print media business.

However, there is still optimism about print media. "Print media still survive because people in the ages over 35 consider it more convenient to read newspaper," said Primus Dorimulu, the Chief Editor of Suara Pembaruan (detikinet.com).

Ninok Leksono, founder of Kompas.com, also mentioned that online media simply allows people to "know" instead of to "read". To know something people will look at the online media, but they need print media to get more information. (detikinet.com).

Therefore, if print media wants to survive in this internet era, they must have good strategy to win the competition. Ade Armando, the former member of the Indonesian Broadcasting Commission (Komisi Penyiaran Indonesia), is convinced that there are opportunities for print media, considering the weaknesses of online media form. "Online media cannot reach the depth of the news in the way print media do," Armando said. He therefore suggests that print media company change their style to serve the news. "If print media still uses hard news style, they cannot compete with the online media," he said. (detikinet.com).

However, when the World Wide Web developed, it gives alternative for publishers. Hundreds of newspaper and magazines published their content on the web (Fidler, 1997; 236). Whether they like it or not, every company must adopt their way to publish in the Internet, including print media.

This trend also happened in Indonesia. When the internet was still considered as new phenomena and appeared to be less promising for media business, there were several daily publishers who used the Internet along with their printed version. Some of them include kompas.com, suarapembaruan.com, bisnis.com, republika.co.id, suaramerdeka.com, pikiran-rakyat.com and many others.

As the second version of printed media, online version objectives are to increase the number of readabilities, because the spreading of the printed version is somehow limited by the transportation or distribution factor. The other benefit of online version for printed media 
publisher is the ability to detect the number and location of their visitors (Cakram Magazine, 2005).

\section{Previous Research}

There are several research done on the scope of print media in internet era. Studies by Nossek, Adoni \& Nimrod (2015) found that print media are still an important component of the new communication environment among European audiences. Half of the population still read print newspaper and print books. They assumed, this finding is related to reading books as an important cultural activity for European audiences.

Kusuma (2016) mentioned that conventional media - including print media - should maintain their credibility and people's trust for their information to survive in the media business.

Visnovsky (2015) suggests that journalist and editor should have multi skills and ability to transform their journalism technique dynamically. He also said that there is a possibility that all media will be full of colour and visually attractive.

In order to avoid becoming a dying business, and remain as a news source, Everett (2011) said that implementing new technologies is important for the print media industry.

Certainly, the ways to implement new technology for print media business will be an important key for their future business. Therefore, one of this research purposes is to find the effective strategy for print media industry to implement new technology.

\section{Print media must change the platform}

Budiono Darsono, founder of detik.com, wants to challenge the concept of online media development when he established detik.com in 1998. "At that time, Kompas and Republika's online media only served as replication of their printed version, published once a week. It doesn't fit with the concept of online media that should not have periodicity. The event should be reported at the same the very second it happened," said Budiono (Kompas, June $17^{\text {th }}, 2011$ ). Budiono Darsono mentioned the reason why established media company in Indonesia failed to develop their online media, "Printed media may be dead, but the media itself is never dead, it just a change of the platform," (Kompas, June $17^{\text {th }}, 2011$ ).

Print media publisher therefore should not regard the web simply as electronic supplements or parallel version for their printed version, to protect and build circulation for their print circulation only. (Fidler, 1997; 236). When print media publisher decided to adopt the Internet for their business, they also have to choose a reliable online strategy. Publisher has to be more creative and has to show 
that they have the courage to experiment with new ideas (Roland Berger, 2008).

The Internet has numerous benefits for the business area, including printed media business. As De Pelsmacker (2003) said, internet can reach consumer directly, give information, create brand awareness, develop brand image, influence the audience to try and buy the product, and develop customer loyalty.

\section{Magazine Going Online}

Magazine, one of the forms of printed media, is also influenced by the growth of the Internet. Some of them are already aware about the use of the Internet to support their print media business.

Data from Magazine

Publishers of America (MPA) confirms that the number of magazine website's visitors in 2008 reached about 70,7 million people per month, at United States, or an increase of 11,9 $\%$ from that of 2007. Magazine Publisher of America also confirmed that now there are more and more magazine publishers that go online, because they want to broaden their product, attract customers who need online magazine content, and also build specific community (www.bizreport.com).

Ulrich Kaiser in 2003 conducted a research on 14 German woman magazines and found some reasons why magazine publishing should also involve creating a website. Some of the reasons include an expectation that there is an opportunity to get online advertisement and the possibility for cross selling. They also made a website because their competitors already embarked in online publishing the number of readers who engaged in online behavior was increasing (www.ulrichkaiser.com).

This phenomenon also happened in Indonesia. In addition to newspaper publishers, magazine publisher has actively adopted internet strategy for their business. There are a number of different kinds of magazine in Indonesia, with different target market. The themes of discussion on these magazines also vary, from news and politics to lifestyle, hobbies, food, celebrity, technology, sport, and many others. One of these categories includes health magazine.

\section{About Nirmala Magazine}

Nirmala is a magazine that focuses on natural health issue. Its first edition was announced on May 1999. To support its mission to educate people about health, Nirmala developed its business by establishing a book publishing, named "Penerbit Buku Populer Nirmala", which provides health service along with Klinik Nirmala Holistik. They also organize health events such as seminar, healthy food cooking demo and other activities. 

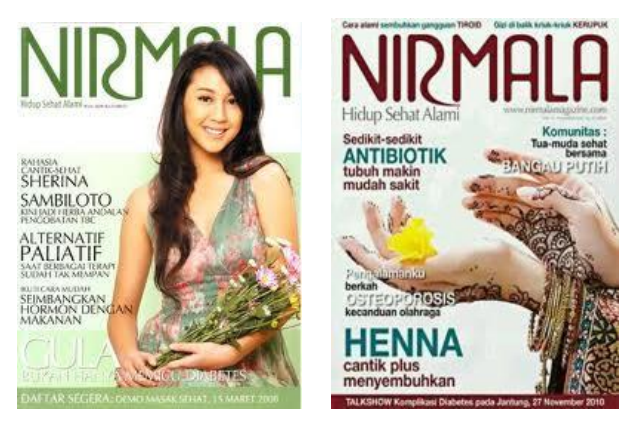

Figure 1. Covers of Nirmala magazine

According AC Nielsen report published in Cakram Magazine in 2005 - six years after Nirmala's first edition - Nirmala is a brand leader at health magazine category. (www.nirmalamagazine.com).

Unfortunately, Nirmala magazine cannot sustain this achievement in the following years. The number of Nirmala magazine readership decreased significantly, from 46,000 readers in 2005 to only 7,000 in 2007. There was an increasing number of readerships in 2008, but the number decreased on the following years, to 1000 in 2010 (AC Nielsen, 2011).

The increasing number of health magazine distribution on the market may become one of the reasons of Nirmala's readership decline. The development of radio, television, and now, the Internet also contributed to this condition.
Actually, from the beginning of its emergence, the founder of Nirmala magazine was also aware about the challenges of electronic media to their business. They realized that this magazine began to be published at the time when electronic media was rising, while the popularity of printed media was predicted to be fading.

Nirmala still chose printed media as the format of the magazine, because they believe that print media will have an important role as valid information source to educate people, to make people more aware about health.

"Pertanyaan pertama yang muncul waktu itu, adalah mengapa majalah? Walaupun media elektronik menunjukkan kemajuan pesat di era teknologi global sekarang ini, namun peranan media cetak 
tetap dominan sebagai rujukan informasi yang valid. Dalam proses ajar-belajar (menerima informasi baru), otak kita menyerap informasi melalui lihat, dengar dan catat. Media cetak adalah catatan yang setiap diperlukan pembaca bisa didapatkan kembali informasi tersebut dengan segera. Sedangkan pada TV atau radio, informasi itu berlalu bersama waktu."

("The first question arose back then was 'Why magazine?' In spite of the fact that electronic media was rapidly developing in the global technology era like nowadays, the role of print media will remain dominant as the valid reference for news. In the process of learning and receiving new information, our brain will absorb information by observing, hearing and making notes. The print media is the notes that any readers can refer back to in an instant, whereas the information given by television and radio will disappear in time") (nirmalamagazine.com).

Although Geoffrey Mc Donald Bowl believe that magazines have some benefits compared to another print media - longer period of life, reaching specific target that can't be reach by another media, and ability to preserve relationship with its loyal customer with offline events - that make magazine business stand among the media competition, but the effect of internet development on its business, should be taken seriously.

\section{Media Business}

We can say that media industries have unique market situation, because it operates in dual market - selling two different types of "products" to two different buyers. "First, they produce the media products (newspapers, magazine, TV programs, etc.) that are marketed and sold to consumers. Second, they provide access to consumer (readers, viewers) that is sold to advertiser" (Albarran at Croteau and Hoynes, 2006: 28).

Besides making profits, business of media also has uniqueness because it deals with ideas, information and culture, informing and entertaining, influencing people about their understanding of the world and themselves (Croteau and Hoynes, 2006: 1).

Just like another business, media certainly also has business strategy to accomplish three general goals, that include maximizing profit, reducing cost, and reducing risk. The strategies used by each media maybe different, but some of them include the 
following: advertising, exploiting synergy by packaging content so it can be used by different media, promoting products across media, developing well- known brand names, and using recent technologies such as the Internet. (Croteau and Hoynes, 2006: 152)

\section{Print Media Transformation In The Internet Era}

\section{Roland Berger Strategy}

Consultant (2008; 3) identified several success factors for publisher, that can help them win customers of their print products in the digital age: 1) Print media can be successful only if it is clearly positioned, 2) Premium readers are the most attractive segment, 3) Print media continue to be attractive in the advertising market, 4) Focus on the competitive advantage of print media in order to differentiate from other media, 5) Growth primarily in niches market, 6) Profitability through content scaling, 7)Younger generations should be trained to become readers and develop a loyalty to print media at an early age, 8) Events as a tool to increase brand awareness, and also next step for profitable diversification, 9) Ability to innovate (www.rolandberger.com).

\section{Website Objective And Strategy}

According to Duncan (2002, p.442), most companies hire a webmaster, to operate the company's website. This webmaster should be someone who understands the design of a site and how it works. A webmaster has the following duties: 1) Monitor and analyze site activity, 2) Use database $\operatorname{logs}$ to document hits and visitor usage, 3) Continuously check for problems, 4) Capture consumer profiles and tracking information about site visits, 5) Post new information so content is always fresh, 6) Continuously test content, navigation, offerings, and response mechanisms,7) Work with all departments to ensure that the information is current and correct.

Duncan also said that there must be an infrastructure in place to handle the details of the business, to fulfill consumer expectation. This infrastructure goes from the person who answers the phone (or e-mail) to someone who does stocking merchandise, and delivers it to the customers.

Beside human resource, company must have enough budget to keep sustainability of the website.

For print media company, revenue from online business will not merely come from direct buying and selling activity and not just to promote their products and services, but also to build strong relationship and encourage transaction process. All activity that support buying and selling process, even without real financial transaction can be done within the site. This kind of website, that supports buying and selling processes is called 
e-commerce website (Chaffey, 2007; 8). In short, Chaffey defines ecommerce as "all electronically mediated information exchange between an organization and its external stakeholders".

There are four types of ecommerce website: a). transactional $e$ commerce site. This site enables consumer to make a purchase online. The revenue comes from product selling. But, the website also gives information for consumer who prefer to buy offline. b). service-oriented relationship-building websites. This site tries to build relations with costumer in order to stimulate purchasing behavior by giving them appropriate information. The products are usually not on sale online. c). brand building sites. The main focus is to support the brand by giving the customer online experience of the brand. d). portal or media sites. Provide information or news. The revenue comes from advertising, or sales commission (Chaffey, 2007; 10). In addition, Kotler and Armstrong (2006: 533) mention two types of website. There are: 1). Corporate website. A website that is designed to build customer goodwill, and as a supplement to another sales channel, rather than to sell the company's product directly. 2). Marketing website. A website that engages consumer in interaction that will move them closer to a direct purchase and other marketing outcome.
We can conclude that developing online strategy is the most important strategy for any company when they go online.

Eventually, Nirmala magazine realized the importance of company website to support their print media business. In 2009, Nirmala developed their company website, www.nirmalamagazine.com.

Along with their company website, Nirmala magazine also used email blast service as their tools to disseminate information to their customer, and owned an account in several social media, such as twitter, linkedin, and facebook. It showed us that Nirmala magazine did not just regard internet as an opponent, but as an important tool to support their business. But the big questions that needs an answer is: "Is that enough?"

The aims of this research are: 1) Analyzing the strategy that are implemented on Nirmala's website to get customer and win the business competition, 2) Analyzing effectiveness of the web to achieve company's objective. 3) Finding any possibility to get optimum benefit from company's website, especially for printed media publishing.

Threfore, the research questions are: what kind of online strategy implemented by Nirmala magazine to support their business? Is that strategy provides optimum benefit to Nirmala magazine, so they can compete with their competitor? 


\section{RESEARCH METHODOLOGY}

The case study, which is used in this research, is one of the qualitative research techniques that is used when researcher want to understand or explain a phenomenon. There are five characteristics of case study research according to Merriam (at Wimmer and Dominick, 2003; 129): a) Particularistic. Focus on particular situation, event, programme or phenomenon. b) Descriptive. Detail description about topic being studied. c) Heuristic. Understanding about topic being studied to get a new perspective. d) Inductive. Principle and generalization emerge from an examination of the data.

Case study is chosen to be used in this study since the objective of this research is to understand what kind of online strategy that are used by Nirmala magazine company. This research will use two techniques of data collection: interview and document review. To get all information needed, researcher interviews some people who give contribution to the site's operational, directly or indirectly. The document being reviewed are the website itself, and the document related with Nirmala's website.

On the data analysis process, researcher will elaborate all data gained with theories that are relevant to this thesis, such as media business, media convergence, e-commerce, website function and design, and online marketing communication strategy. The aim of this analysis process is to understand the strategy used by Nirmala on executing their company website, and also to find any possibility to get optimal benefit from it.

\section{RESEARCH FINDINGS AND DISCUSSION \\ Website Objective}

If e-business strategy is not clearly defined, the company may miss opportunity as the result of the lack of evaluation of opportunities or insufficient resourcing of e-business initiative. As a result, savvier competitor will gain the advantages. The company may set inappropriate direction of business strategy (Chaffey, 2007, p.204).

To avoid these problems, Chaffey recommends traditional organization to implement e-business, to made e-business strategy based on corporate objective (which markets to target and revenue generations from electronic channel). These objectives should be based on new opportunities and threat related to electronic network adoption (Chaffey, 2007, p.204).

\section{Marketing Communication Tools}

According to Syamsir Alam, member of Nirmala's website development team, at the beginning of website development planning process, nirmalamagazine.com will be used as a 
promotion tools for Nirmala magazine and its activity, including Nirmala's clinic program.

On the draft of letter of agreement of CV Diodachi IT Solutions with PT Narya Eka Wisesa in 2009, CV Diodachi IT Solutions will have to develop Nirmala magazine's website with these features: Home (Company Profile, History, Board of Management, FAQ, circulation), New Edition (cover, articles preview, person in charge), Consultation (Expert Q\&A, Online Q
\&A), Events (Promotional calendar, photos of activities, sponsorship, online registration form), Contact Us, Ads (rate card, online ads booking), Friends of Nirmala (registration form, latest info), Subscription (list of books, magazines, subscription forms), tips, news (latest health news, health news outside the magazines), circulation (distribution map, newsstand list), miscellaneous (tips and suggestions), polling and pengalaman pengunjung (readers experience).

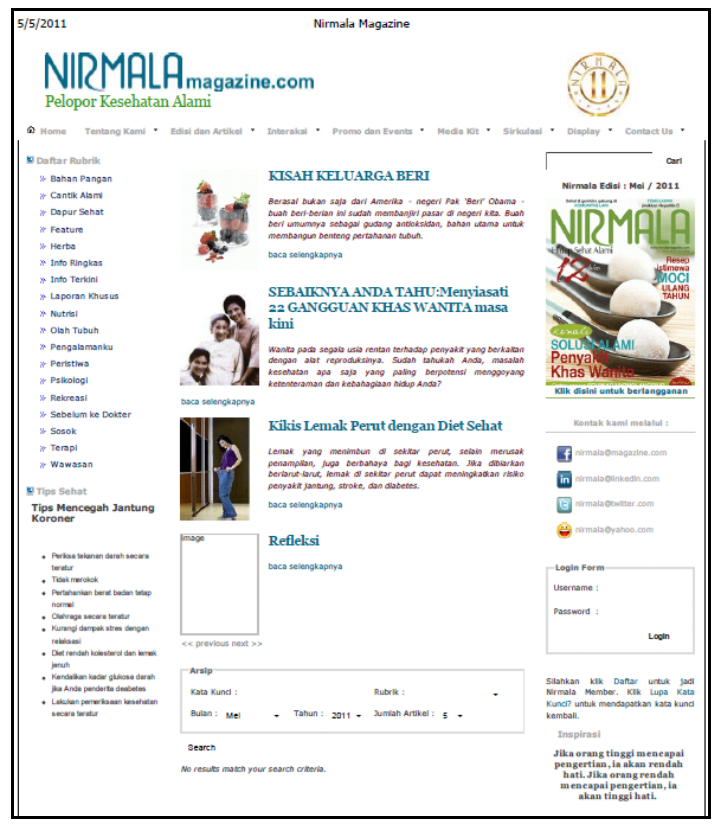

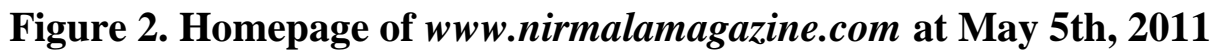

Some of these features, such as: edisi terbaru (latest edition), berlangganan (subscription), sirkulasi (circulation), and events obviously show us that this website is geared to be the promotion tools for the existing business of PT Narya Gunatra. As it has been widely accepted, the Internet is actually one of the marketing communication tools, together with any other promotion activity such as: advertising, public relations, sales promotion, direct marketing, personal selling, and sponsorship.

The Internet itself can support company's marketing communication 
strategy from many different sides: research and planning, distribution, customer service, corporate communication, and marketing communication activity (Kitchen and Pelsmacker 2004: 32-95, 112-113).

\section{New Medium To Attract Online Advertisement}

The increasing rate of magazines sales figure means increasing income. However, it is not the only way of this website to give revenue for the company. Samsir and Jose (coordinator for website development) said that this website is planned from the beginning to get advertisement. "That's why there is special page of advertisement rate card," Samsir explained.

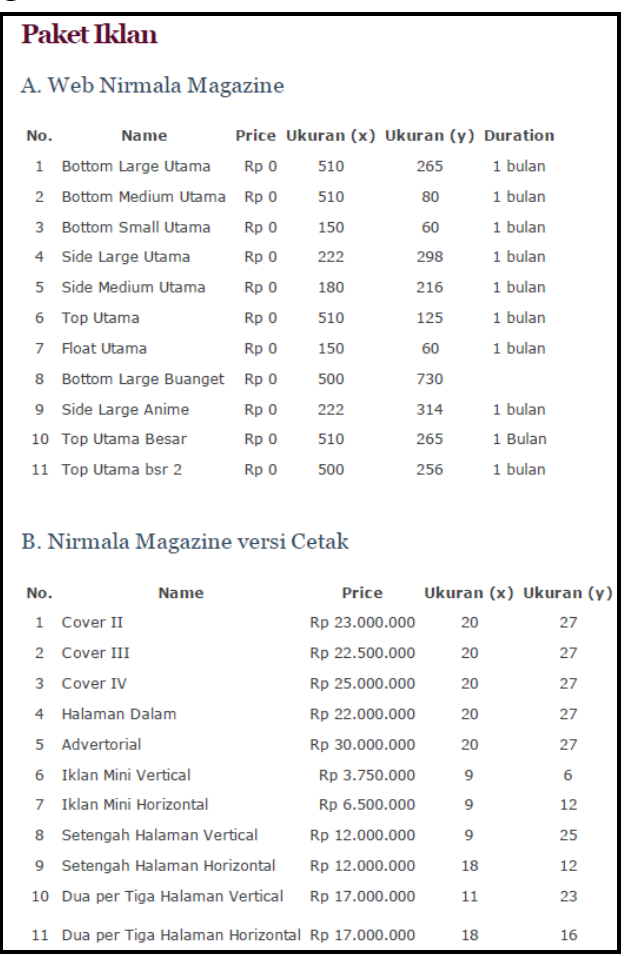

Figure 3. Information about advertisement rate on Nirmala's website

Hermaini, Nirmala's marketing staff also admitted that she rarely offers Nirmala's site as a place for her client to put on their advertisement. Because the website is not well maintained. Meanwhile, Ana, also from the marketing department, said that they offer it to the advertiser, but mostly only as a gift or bonus.
When the site was accessed on July $28^{\text {th }}$, 2011, there was no advertisement from another party, while there were several advertisements on the printed version, for the June and July edition. In brief, the use of this website as the bonus to advertisers of printed magazine is not yet optimal. 
Actually, James Gentry, the dean of the school of journalism at the University of Kansas said that there were 50 media partnerships or affiliations in US practicing convergence in order to increase advertising revenue brought by higher ratings, more subscriber or more website traffic (Gentry in LawsonBorders, 2008, p. 7).Therefore, this website, if properly managed, have an important implication to the marketing division, in order to increase revenue from advertisement.

\section{Is this Objective Effective?}

However, explicitly, Andang Gunawan, founder of Nirmala Magazine, said that this website is not intended to give financial benefit to the company. Andang fails to understand the opportunities or potentials of the website to bring financial benefit for her company. However, when she was asked about financial benefit expected from this site, Andang finally mentioned "At least this website income could support its operational costs."

Based on her answer, the main objective of this website is not to gain financial objectives, but to increase the number of magazine's readers and subscribers and also increases the number of Nirmala's event participant. Yet, certainly these objectives cannot be valued as an effective objective, because the SMART mnemonic (Specific, Measurable, Achievable,
Realistic, and Time constraint) required by Chaffey (2007, p.349) to test the value of objective cannot be fulfilled. Whereas, Chaffey said that effectiveness of e-marketing plans is based on clearly defined objectives that will inform strategies and tactics. Poorly defined objectives will give wrong emphasis on which side of the company being promoted by the website.

\section{Website Types}

As Chaffey said, there are various ways in which the company use website to sell their products, according to the market they serve. However, Chaffey mentioned four main site functions. There are: sales transactions, service-oriented relationship-building, brand building, and providing news (2007, p.10).

\section{Brand Building Site}

Nirmala's website is equipped with several pages to disseminate understanding about the company, mission and its product, such as: tentang kami (about us), history, calendar and Foto Kegiatan (photos of activities). If we compare them with four main website functions from Chaffey, we can say that Nirmala's website has brand building function, since Chaffey said that focus of brand building site is to provide online experience to support the brand.

The pages tentang kami (pengantar, history, and board of 
management page) for example, contains foreword from the founder of Nirmala magazine, Andang Gunawan, which is also an explanation about the change of lifestyle that bring in a number of health disorders to human life as the reason why they publish a health magazine. Features that also give website visitor information and understanding about its product are Daftar Rubrik (rubric list), Articles, and photo kegiatan (photo activities).

\section{Serviced-Oriented Relationship- Building Site}

To obtain information about its visitor, there is the website membership $\log$ in form. This form appears in the right side of Nirmala's homepage. According to Jose, log in form is intended to collect database. Log in means that they have to provide their identity, including username, first name, last name, address, company name, phone number, and mobile phone number.

Some of this website features also require visitors to register as a member to be able to see the information. But, until May 2011, according to the data from PT. Narya Eka Wisesa, visitors of this website who logged in as a member was recorded at only 275 persons. If we compare with the number of visitors every month, which is in the range of 1,500 unique visitors, from January until March 2011 (according to log file data), we can see that only small number of visitors who are interested to become a member. Therefore, it can be assumed that only small number of Nirmala's website visitor who can reach all of information provided completely, since there is requirement to register as a member on several features.

Nirmala's website also equipped with interaksi link (interaction link that include Tanya jawab ahli (expert $Q \& A)$, Tanya jawab Online (Online $Q \& A$ ), Kritik dan Saran (suggestion and advice), and Polling) that give a chance to the company to make interaction with their potential customer, but these useful features also seem to be poorly managed.

The most helpful page in this website is contact us pages (email us, person in charge (promosi/sirkulasi/iklan (promotion, circulation and ads, peta (maps), alamat address and no rekening (account number), because they give information about any kind of communication channel available, if website visitor wants to contact Nirmala magazine. 


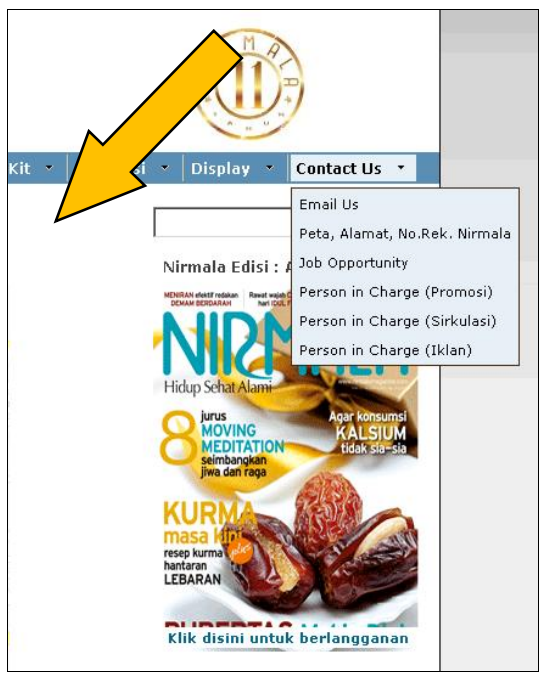

Figure 4. Contact Us feature

These pages can be used as a means to cultivate close links with customer, and any other stakeholder. Customers who need after sales service can also take advantage from this information.

\section{Transactional E-Commerce Site}

Another website function mentioned by Chaffey (2007, p.10) is sales transaction. Not just enabling customer to buy products online, it also provides information for potential customer who prefer to buy offline.

In order to get new customers, in this case new magazine readers and subscribers, Nirmala is actually equipped with useful pages, such as: area penjualan majalah (magazine areas sales), info alamat dan nama agen (address and newsstand) and berlangganan (subscription). Unfortunately, all of these features are not managed properly.
At the 'area penjualan majalah' (magazine area sales) website visitors will not find detailed address and phone number that will make it easier for the customers to get the magazine. Link that will direct visitor to the formulir berlangganan (subscription form) page also cannot be open directly. Visitors are obliged to $\log$ in to this website and become a member. This obligation to give their personal data before visitor are sure about buying product and totally trust the company will inconvenience the consumer, and there is a possibility that visitor will leave the page or even the site immediately.

As Klanac said (2009), “... since trust is crucial in online commerce, when trust between company and customer is not far developed on any stage of communication, the users will not be not willing to provide much of their personal 
information. It means that all requirements for user identification should preferably be avoided."

It will be advisable if the personal identity is required at the end of process. The only page that can help visitor to get the right person to ask is in the contact us page - person in charge (sirkulasi/ circulation). This page gives address of Nirmala's magazine office, contact person, phone number and email address of circulation division staff.

\section{Media Site}

Since there is such information, summary from print edition, this website also serves the function as media sites. However, some people I interviewed seem to be unsatisfied with this site performance.

They thought that function of the website as a portal or media site needs to be sharpened. "It should serve the function as news provider. So, when people need health information, they go to Nirmala's site, not to the Kompas Health, for example," said Kholil from editorial division. However, if we compare to four type of e-commerce website of Chaffey, we can see that Nirmala's site have all of its functions: transactional, serviceoriented relationship-building, brand building and portal, although some of these features are not well managed or need improvement.

Table 1. Nirmala's website function

\begin{tabular}{|c|c|c|}
\hline Function & Objective & Features \\
\hline Research and planning & $\begin{array}{l}\text { Obtain } \\
\text { stakeholder } \\
\text { information }\end{array}$ & $\begin{array}{l}\text { - Website membership (log in } \\
\text { form) } \\
\text { - "kritik dan saran" (suggestion } \\
\text { and advice page } \\
\text { - "polling" page } \\
\text { - Contact us (email us, peta } \\
\text { (maps), alamat (address), no } \\
\text { rekening (account number), } \\
\text { person in charge) }\end{array}$ \\
\hline Distribution & $\begin{array}{l}\text { product } \\
\text { offering and } \\
\text { order taking }\end{array}$ & $\begin{array}{l}\text { - } \text { Area penjualan majalah } \\
\text { (magazine sales areas) } \\
\text { - Info alamat dan nama agen } \\
\text { (newsstand names and } \\
\text { addresses) } \\
\text { - Formulir berlangganan } \\
\text { (subscription forms) } \\
\text { - Contact us/Person in charge }\end{array}$ \\
\hline
\end{tabular}




\begin{tabular}{|c|c|c|}
\hline & & (sirkulasi/circulation) \\
\hline Customer service & $\begin{array}{l}\text { customer } \\
\text { relationship, } \\
\text { loyalty } \\
\text { building, } \\
\text { updates of } \\
\text { information, } \\
\text { answer } \\
\text { customer's } \\
\text { questions, } \\
\text { after sales } \\
\text { services. }\end{array}$ & $\begin{array}{l}\text { - FAQ } \\
\text { - Contact us (email us, peta } \\
\text { (map), alamat (address), no } \\
\text { rekening (account number), } \\
\text { person in charge). }\end{array}$ \\
\hline $\begin{array}{l}\text { Corporate communication } \\
\text { tools }\end{array}$ & $\begin{array}{l}\text { disseminate } \\
\text { information } \\
\text { about the } \\
\text { company } \\
\text { and product, } \\
\text { reinforce } \\
\text { corporate } \\
\text { identity, } \\
\text { improve } \\
\text { company } \\
\text { image, } \\
\text { to interact } \\
\text { with its } \\
\text { audience. }\end{array}$ & $\begin{array}{l}\text { - "tentang kami” (about us) } \\
\text { page (pengantar } \\
\text { (introduction), history, board } \\
\text { of management). } \\
\text { - Magazine cover } \\
\text { - "daftar rubrik/rubric list" } \\
\text { (bahan pangan (food } \\
\text { ingredients), cantik alami } \\
\text { (natural beauty), dapur sehat } \\
\text { (healthy cuisine) } \\
\text { - Page "edisi dan artikel } \\
\text { (articles and editions) topic } \\
\text { mendatang (incoming topics), } \\
\text { berita kesehatan (health news) } \\
\text { - Promo dan events page } \\
\text { - Profil pembaca (readers' } \\
\text { profile) } \\
\text { - Nirmala shop } \\
\text { - Sahabat Nirmala (friends of } \\
\text { Nirmala) } \\
\text { - Tanya jawab ahli (expert Q \& } \\
\text { A) } \\
\text { - Tanya jawab online (online Q } \\
\text { \&A) } \\
\text { - Kritik dan saran (Suggestion } \\
\text { and advice) } \\
\text { - Folling } \\
\text { - Contact us }\end{array}$ \\
\hline
\end{tabular}




\begin{tabular}{|c|c|c|}
\hline & & $\begin{array}{l}\text { - Twitter } \\
\text { - Facebook } \\
\text { - LinkedIN } \\
\text { - YM }\end{array}$ \\
\hline $\begin{array}{l}\text { Marketing communication } \\
\text { tools }\end{array}$ & $\begin{array}{l}\text { reaching and } \\
\text { informing } \\
\text { customer, } \\
\text { create brand } \\
\text { awareness, } \\
\text { reinforce } \\
\text { brand } \\
\text { images and } \\
\text { brand } \\
\text { attitudes, } \\
\text { stimulate } \\
\text { customer to } \\
\text { take action, } \\
\text { try the } \\
\text { product then } \\
\text { make a } \\
\text { purchase, } \\
\text { building } \\
\text { relationship } \\
\text { and loyalty. }\end{array}$ & $\begin{array}{l}\text { - Area penjualan (sales area) } \\
\text { - Info nama dan alamat agen } \\
\text { (newsstand names and } \\
\text { addresses) } \\
\text { - Formulir berlangganan } \\
\text { (subscription form) } \\
\text { - Banner } \\
\text { - Media kit ("profile pembaca } \\
\text { (readers' profile" and "rate } \\
\text { card iklan (ads rate card") } \\
\text { - Page "promo dan event } \\
\text { (promotion and event), } \\
\text { Kalender promosi } \\
\text { (promotional calendar), foto } \\
\text { kegiatan (photos of activities), } \\
\text { - Nirmalashop } \\
\text { - Nirmala message service } \\
\text { running text }\end{array}$ \\
\hline
\end{tabular}

(research result, 2012)

What Samsir expected is to develop Nirmala's website to become a portal or media sites. This type of website focuses on providing information or news to the customer, and the revenue comes from advertising, or sales commission.

Certainly, Nirmala's existing website needs a lot of change on its execution.

Andang said that she had seen that some international magazine already commercialized their website. "Some publishers just give their abstract on the web and if the audience want to read the complete story then they have to pay for it, to get online content or become their printed edition subscribers," Andang told.

Actually, on his books, Chaffey (2007) mentions several possible techniques for publisher to generate revenue, such as: subscription access to content, pay per view access to document, cost per thousand advertising on site, cost per click advertising on site, sponsorship, and affiliate revenue.

Nirmala's website could also be used as one of these revenue 
models to generate income for their company. Therefore, this website can give contribution to the business.

\section{CONCLUSION}

At the beginning of the process of website development, there was a resistance to go online because of some concerns that this website will become a competitor for the existing print media business. Therefore, in most cases, website is not intended as another business line, only a supporting tool for print media business that was first established.

The site also promotes Nirmala's activities or events, and becomes the medium to attract online advertisers. To support this website objectives, the site is equipped with many features, such as: Tentang Kami (About Us), Edisi dan Artikel (Edition and Articles), Interaksi (Interactions) and Promo and Events, Media Kit, Sirkulasi (circulation), Display, and Contact Us.

All these website featuresregardless of how they execute the website afterwards, the quality of content, content management, easiness for website visitor to acquire content needed, and infrastructure prepared to serve all possible website visitor demand - have actually met the requirement of the four types of ecommerce website, mentioned by Chaffey: brand building, relationship building, transactional, and news provider.
The website, if managed properly can help the magazine company to obtain information about their consumers, clients, and prospects; offer products and process customer order, organize after sales service, develop relationship with their stakeholder, and build customer loyalty. This website also has the capacity to disseminate information about the company and its products to the market, reinforce corporate identity and image, and will finally stimulate customers to take actions, to try the products, and make a purchase. It means that this website can support Nirmala magazine marketing activity as well as to gain the direct online revenue.

Unfortunately, this website does not give optimum benefit - either for printing out business or giving the direct revenue from the online side. Certainly, the use of new media for print media business, in this case, Nirmala magazine, needs a lot of improvement.

The lack of understanding about the optimum benefit they can get from online side, poor decision about online revenue opportunity, target market differentiation, strategy, infrastructure, budget, management team, and synergy with all business units are all factors that need to be improved on Nirmala's website management.

Based on the findings, the researcher suggests that: 1) Nirmala 
magazine company must have further discussion with all of business division in adopting internet to their business process and make a proper online communication strategy for company and each business unit level to increase their business performance. 2) Nirmala should develop solid website management team, consisting of capable resources to execute all parts of online strategy, with full support from all magazine divisions. 3) Nirmala should modify the website content and design, equip the site with features that are most suitable and needed by online users, and use any online optimum method to deliver the traffic to the site.

Further research on what kind of website needed by magazine readers is necessary to be conducted, since this research only uses several research results on the online users' behaviors. The studies do not specifically examine the online magazine readers' behaviors.

Researcher hopes that this study analysis and results can serve as an evaluation for Nirmala magazine company to improve their online strategy implementation, in order that the website they developed can give optimum benefit to the business. Hopefully, the results analysis, expert theories, data, facts, and all information stated in this research can also serve as a guideline for any printed media publishing, to adapt with the internet era.

\section{REFERENCES}

Bubanja, Marijana \& Bubanja, Iva, 2015, Competitive Management Strategy for Print Media Advertising Activities, Journal of Engineering Management and Competitiveness Vol. 5, No.2, 2015, p.68-76.

Cakram magazine, special editions of magazine and tabloids, 2005.

majalah dan tabloid Mei 2007

Chaffey, 2007, E-Bussiness and ECommerce Management,

England: Pearson Education Limited,

Clow and Back (2010) Integrated Advertising, Promotion, and Marketing Communication, New Jersey: Pearson Education

Croteau, Hoynes (2006), "The

Business of Media-Corporate

Media and the Public Interest"

California: Pine Forge Press.

Duncan, Tom (2002), IMC: using Advertising and Promotion to Build Brands, New York: McGraw Hill.

Everett, C. Elizabeth

(2011)

Transformation of Newspapers in the Technology Era, The Elon Journal of Undergraduate Research in Communication Vol. 2 No.2, retrieved from https://www.elon.edu/docs/eweb/academics/communications/ research/vol2no2/09EverettEJFal 111.pdf 
Fidler,

Roger

(1997),

Mediamorphosis: Understanding New Media, California: Pine Forge Press.

Harris and Dennis (2008), Marketing the E-Bussiness, New York: Routledge

Harrower, Tim. (2009), Inside Reporting: a practical guide to the craft of journalism. New York: McGraw Hill.

Herdiansyah, Haris, 2010, Metode Penelitian Kualitatif, Jakarta: Greentea.

Hadi, Ido Priyana, 2003, Konsep

Penulisan Jurnalistik Masa

Depan dan Storyboard untuk

Online News, Nirmana vol.5

retrieved from

www.puslit2.petra.ac.id/ejournal/ index.php/dkv/article/viewFile/1 6098/16090 downloaded at July $\left.7^{\text {th }}, 2011\right)$

http://www.poynterextra.org/et/i.htm http://strategimanajemen.net/2009/05/

18/revolusi-digital-dalammembaca-pengetahuan-daninformasi/ pada 20 November 2010

http://www.saputramz.com/2009/10/ki

las-balik-tujuan-internet-

diciptakan (downloaded at 20

November 2010)

http://www.lasembiz.com/tag/survey-

pengguna-internet-di-indonesia

pada 20 November 2010.

http://internetworldstats.com/ http://www.bizreport.com/2008/05/onl ine_consumer_magazines_attract _more_readers.html\#

http://www.nirmalamagazine.com Infocom Competence Center Roland Berger Strategy Consultant (2008), There's Life in the Old Dog Yet - Print Media in the Digital Age, Munich: Roland Berger Strategy Consultants (downloaded at February 22 ${ }^{\text {nd }}$, 2011

from www.rolandberger.com)

Iriantara, Yosal (2008), Media Relations: Konsep, Pendekatan, dan Praktik, Bandung: Simbiosa Rekatama Media.

Jawa Pos Tetap Nomor satu di Indonesia - Survey Nielsen, Jpnn mobile, December $10^{\text {th }}, 2010$ (http://m.jpnn.com/news.php?id= 79233 , downloaded at June $24^{\text {th }}$, 2011.

Kitchen, P.J. and Pelsmacker, Patrick De (20040, Integrated Marketing Communication: a Primer. Taylor and Francis e-library.

Klanac, Natasa Golik (2008), Dimensions of Customer Value of Website Communication in Business-to-Business relationships. JBM vol. 2, DOI 10.1007/s12087-008-0027-8

Klanac, Natasa Golik (2009), Website Communication and Business relationship - matches and Mismatches. JBM 3: 115-128 retrieved from www.springerlink.com. 
Kusuma, Satria (2016), Posisi Media Cetak di Tengah Perkembangna Media Online di Indonesia, InteAct, Journal on Communication Vol 5 No.1, retrieved from http://ojs.atmajaya.ac.id/index.ph p/fiabikom/search/search.

Koufaris, Marios, 2002, Applying the Technology Acceptance Model and Flow Theory to Online Consumer Behavior, Information System Research Vol. 13 No. 2, June 2002, p. 205-223

Kaiser, Ulrich, 2003, Why do Magazines Go Online? Retrieved from

http://www.ulrichkaiser.com/pap ers/when.pdf

Konvergensi Media dan Masa Depan Bangsa. PDF, Soekartono SIP, MSi, (ww.soekartono.info at June 26yh, 2011).

Lawson-Border, Gacie (2008). Media Organizations and Convergence: case studies of media convergence pioneers, Taylor \& Francis e-Library.

Mohammed R., Fisher, R.J., Jaworksi, B.J., and and Paddison, G. ( 2003) "Internet Marketing Building Advantages in a Networked Economy" , Singapore: Mc Graw Hill, p.342 Mesquita, Rafael, 2017, The Transition of a Traditional Newspaper to the Internet Age: an Historical Account of Le Monde's Case, Observatorio
Journal, vol. 11, p. 54-60, retrieved from http://www.scielo.mec.pt/pdf/obs /v11n1/v11n1a04.pdf

Attitude and Behavior Pengguna Internet di Indonesia (http://themarketeers.com/archives/attitude -and-behavior-penggunainternet-di-indonesia.html)

Menghitung Peluang Media Cetak VS

Media Online, detikinet.com

March 22th, 2010

(http://www.detikinet.com/read/2 010/03/22/154146/1322920/398/

menghitung-peluang-mediacetak-vs-media-online at June 24th, 2011)

Menulis berita di media cetak dan media elektronik, retrieved from https://docs.google.com/viewer?a =v\&q=cache:OjJCK9Fb5YcJ:w ww.tempo-institute.org/wpcontent/uploads/2009/09/Menulis -Berita-di-Media-Cetak-danMedia-Elektronik.pdf

Media online migration - will the internet make traditional media obsolete?

(www.theopennewsroom.com/do cuments/media_online_migration .pdf, downloaded at February $\left.22^{\text {nd }}, 2011\right)$.

Nossek, Hillel., Adoni, Hanna \& Nimrod, Galit. (2015) Is Print Media Really Dying? The State of Print Media Use in Europe, International Journal of Communication 9: 365-385. 
Purhantara, Wahyu, 2010, Metode Penelitian Kualitatif untuk Bisnis, Yogyakarta: Graha Ilmu.

Quinn, Stephen. and Filak, Vincent F., (2005), Convergent Journalism: an Introduction, Oxford: Focal Press.

Survey Nielsen: Pembaca Media Cetak makin Turun, kompas.com July $16^{\text {th }}, 2009$

(http://worldcup.kompas.com/rea d/2009/07/16/16015757/survei.ni elsen.pembaca.media.cetak.maki n.turun at June 24th, 2011).

Tandon, Satish, 2007, The Future of Print News Media: Adapting to Change, Journal of Global Media Studies Vol.2, p. 37-42. Retrieved from http://citeseerx.ist.psu.edu/viewd oc/download;jsessionid=DD1955 24855D156BB9C533E87D5982 02?doi=10.1.1.466.4663\&rep=re p1\&type $=$ pdf

Visnovsky, Jan (2015). Print Journalism in the Era of Electronic Media, Mediterranean Journal of Social Science vol. 6: 48-54

Doi:

10.5901/mjss.2015.v6n6s2p48

Wimmer, RD. and Dominick, JR, 2003, Mass Media Research an Introduction, US: Wadsworth.

Xie, En \& Teo, Hock-Hai \& Wan, Wen (2006), Volunteering Personal Information on the
Internet: Effect of Reputation, Privacy Notives, and Rewards on Online Consumer Behavior, Market Lett 17: 61-74, DOI 10.1007/s11002-006-4147-1

\section{Nirmala's Document}

nirmalamagazine.com log file data, accessed at March 14th, 2011 (from Jose Gunawan)

draft perjanjian pekerjaan pembuatan aplikasi website Nirmala Magazine (PT Narya Eka Wisesa) dengan CV Diodachi IT Solutions (2009)

Hasil angket pembaca Nirmala tahun 2010 (litbang Nirmala)

Profil pembaca Nirmala (prepared by Samsir Alam, December 2010 for Nirmala's content refreshment meeting).

Situs Kesehatan dan Peluang Bisnis Website (prepared by Samsir Alam as introduction for web content meeting).

Tingkat laku tahun 012002 s.d. tahun 032011 (from financial division)

Nirmala's product, brochure, and documentation.

Health magazine readership data from 2007 - 2011 (AC Nielsen, 2011) 